\title{
Large-scale ruthenium- and enzyme-catalyzed dynamic kinetic resolution of (rac)-1-phenylethanol
}

\author{
Krisztián Bogár, Belén Martín-Matute and Jan-E. Bäckvall
}

\section{Full Research Paper}

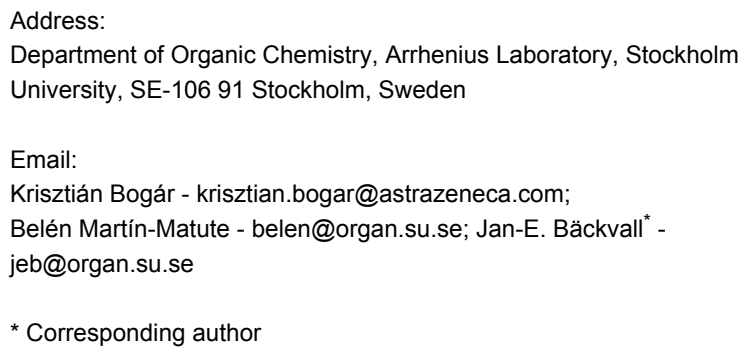

Beilstein Journal of Organic Chemistry 2007, 3, No. 50 doi:10.1186/1860-5397-3-50

Received: 06 November 2007

Accepted: 20 December 2007

Published: 20 December 2007

C 2007 Bogár et al; licensee Beilstein-Institut

License and terms: see end of document.

\begin{abstract}
The scale-up of the ruthenium- and enzyme-catalyzed dynamic kinetic resolution (DKR) of (rac)-1-phenylethanol (2) is addressed. The immobilized lipase Candida antarctica lipase B (CALB) was employed for the resolution, which shows high enantioselectivity in the transesterification. The ruthenium catalyst used, $\left(\eta^{5}-\mathrm{C}_{5} \mathrm{Ph}_{5}\right) \mathrm{RuCl}(\mathrm{CO})_{2} \mathbf{1}$, was shown to possess very high reactivity in the "in situ" redox racemization of 1-phenylethanol (2) in the presence of the immobilized enzyme, and could be used in $0.05 \mathrm{~mol} \%$ with high efficiency. Commercially available isopropenyl acetate was employed as acylating agent in the lipase-catalyzed transesterifications, which makes the purification of the product very easy. In a successful large-scale DKR of 2 , with 0.05 mol\% of 1, $(R)$-1-phenylethanol acetate (3) was obtained in $159 \mathrm{~g}$ (97\% yield) in excellent enantiomeric excess (99.8\% ee).
\end{abstract}

\section{Background}

Chiral alcohols are important synthetic intermediates and are structural elements in biologically active compounds and natural products. [1-4] A few methods have been developed for the enantioselective synthesis of chiral alcohols including catalytic asymmetric hydrogenation [5-14] and enantioselective hydride addition $[15,16]$ of prochiral ketones, asymmetric dialkylzinc addition to aldehydes, $[17,18]$ and asymmetric aldol reactions. [19-23] Biocatalysts have also been successfully employed in the enantioselective reduction of ketones.[24] The enzymatic resolution of racemic alcohols is a convenient alternative for preparing enantiomerically pure alcohols, $[1,25-28]$ and recently this approach has been extended to dynamic kinetic resolution (DKR) by combining the enzymatic resolution with a metal-catalyzed racemization. [29-37] Today, many stable lipases are commercially available and they are frequently used in synthetic organic chemistry.[27]

In the course of the chemo-enzymatic synthesis of optically pure alcohols and esters, Candida antarctica lipase B (CALB) was found to be one of the most active and selective biocatalysts compared to other enzymes. Lipases do not need the presence of a cofactor and they can be employed in pure organic solvents.[38,39] CALB is immobilized on polyacrylate and this increases its thermostability and makes it easy to recover from 
the reaction mixture. Recently, we have developed highly efficient DKR protocols for secondary alcohols in which the traditional enzymatic resolution is combined with an "in situ" racemization of the substrate using a ruthenium(II) racemization catalyst (1) at ambient temperature (Figure 1).[32,34]

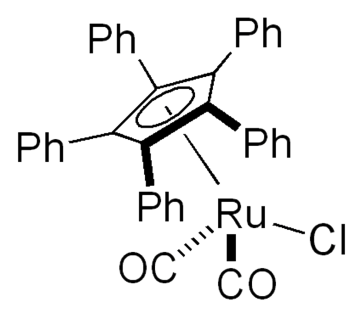

1

Figure 1: Racemization catalyst 1

Many 1-arylethanols are used as intermediates for the synthesis of pharmaceuticals and agrochemicals, [40,41] and they are therefore needed in enantiomerically pure form. Herein, we address some of the scale-up issues of the ruthenium- and enzyme-catalyzed DKR of ( $r a c)$-1-phenylethanol under mild conditions.

\section{Results and Discussions}

The DKR of 1-phenylethanol has been tested under different reaction conditions with the aim of decreasing the catalyst loading. When the reaction is performed on a $1 \mathrm{mmol}$ scale, 4 mol\% of ruthenium complex $\mathbf{1}$ is used for an efficient reaction.[32,34] We believe that the need of this high catalyst loading is due to a fast decomposition of the ruthenium active intermediates in the presence of small amounts of molecular oxygen. To test this hypothesis, the DKR of 1-phenylethanol under argon was compared to the DKR of 1-phenylethanol (2) under an oxygen atmosphere (Scheme 1).

While $98 \%$ of enantiomerically pure ( $>99 \%$ ee) $(R)-1$ phenylethanol acetate (3) was obtained in only 3 hours under an argon atmosphere, only $60 \%$ of $\mathbf{3}$ was produced after 16

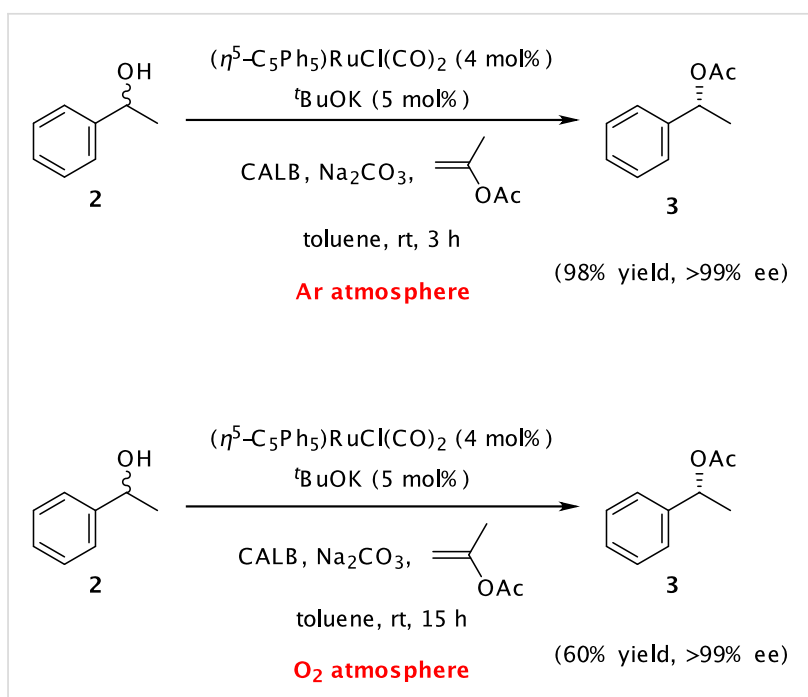

Scheme 1: DKR of 1-phenylethanol under an Ar atmosphere (top) and DKR of 1-phenylethanol under an $\mathrm{O}_{2}$ atmosphere (bottom).

hours under an oxygen atmosphere. We envisioned that running the reaction on a larger scale would allow a decrease in the catalyst loading, since decomposition of the catalyst due to the presence of traces of molecular oxygen may be avoided. The reaction in Scheme 1 (under argon) was therefore run on a larger scale and the results are summarized in Table 1 . On a 10 mmol-scale, $1 \mathrm{~mol} \%$ of Ru-catalyst 1 can be used to achieve $90 \%$ yield of acetate 3 ( $99 \%$ ee) after $18 \mathrm{~h}$ at room temperature (entry 1). A decrease of the catalyst loading to $0.5 \mathrm{~mol} \%$ afforded $87 \%$ of enantiopure acetate, although a longer reaction time was required (42 h, entry 2 ). A significant improvement was obtained when the reaction was carried out at $40^{\circ} \mathrm{C}$ (entry 3). At this temperature, $0.5 \mathrm{~mol} \%$ of catalyst $\mathbf{1}$ is sufficient to obtain a quantitative yield $(99.5 \%)$ of the enantiomerically pure acetate 3 ( $>99 \%$ ee) within $18 \mathrm{~h}$. The very high efficiency of the latter reaction suggests that the racemization catalyst loading can be further decreased, and that an increased reaction temperature may facilitate this decrease.

Indeed, a DKR reaction at $70^{\circ} \mathrm{C}$ on a 1 mol-scale employing only $0.05 \mathrm{~mol} \% \mathrm{Ru}$-catalyst in a more concentrated reaction

\begin{tabular}{|c|c|c|c|c|c|c|c|c|c|c|}
\hline Entry & $2(\mathrm{mmol})$ & $\begin{array}{c}{[\mathrm{Ru}]} \\
(\mathrm{mol} \%)\end{array}$ & $\begin{array}{l}\text { tBuOK } \\
(\mathrm{mol} \%)\end{array}$ & $\begin{array}{c}\text { CALB } \\
(\mathrm{mg} / \mathrm{mmol})\end{array}$ & $\begin{array}{c}\mathrm{Na}_{2} \mathrm{CO}_{3} \\
(\mathrm{mg} / \mathrm{mmol})\end{array}$ & $\mathrm{T}\left({ }^{\circ} \mathrm{C}\right)$ & $\begin{array}{l}\text { Ratio 2/solv } \\
\qquad(w / w)\end{array}$ & time & $\begin{array}{c}\text { Yield of } \mathbf{3} \\
(\%)\end{array}$ & $\begin{array}{c}\text { ee of } 3 \\
(\%)^{b}\end{array}$ \\
\hline 1 & 10 & 1 & 1.5 & 2 & 50 & $\mathrm{rt}$ & 0.14 & $18 \mathrm{~h}$ & $90^{c}$ & $>99$ \\
\hline 2 & 10 & 0.5 & 0.75 & 2 & 25 & $\mathrm{rt}$ & 0.28 & $42 \mathrm{~h}$ & $87^{c}$ & $>99$ \\
\hline 3 & 10 & 0.5 & 0.75 & 2 & 25 & 40 & 0.28 & $18 \mathrm{~h}$ & $99.5^{\mathrm{C}}$ & $>99$ \\
\hline 4 & 1000 & 0.05 & 0.075 & 0.5 & 21.2 & 70 & 0.94 & $20 \mathrm{~h}$ & $97^{d}$ & $>99$ \\
\hline 5 & 10000 & 0.01 & 0.015 & 0.1 & 3 & 70 & 20.1 & $21 d$ & $87^{d}$ & 97 \\
\hline
\end{tabular}

a. Toluene was used as solvent. b: ee measured by GLC; c: Yield measured by GLC; d: Isolated yield by distillation. 
mixture afforded enantiopure acetate 3 in $97 \%$ yield after $20 \mathrm{~h}$. Careful analysis of the enantiomeric purity of acetate 3 revealed that it was $>99.8 \%$ ee. This result is remarkable since only a very low catalyst loading is employed and in addition, only $150 \mathrm{~mL}$ of toluene as the solvent is used to produce $159 \mathrm{~g}$ of enantiomerically pure 3 . Finally, to prove the high efficiency of the racemization catalyst 1 , DKR was carried out on a 10 mol-scale employing lower amount of metal- and biocatalyst in a more concentrated reaction mixture. After 21 days, enantiomerically enriched acetate $3(97 \%$ ee) was obtained in $87 \%$ yield (corresponds to $1.43 \mathrm{~kg}$ ). The remaining alcohol had an ee of $19 \%$, demonstrating the high racemization ability activity of ruthenium complex $\mathbf{1}$.

\section{Conclusion}

In this article, some of the scale-up issues in the rutheniumand enzyme-catalyzed DKR of ( $r a c$ )-1-phenylethanol were investigated. Under optimized reaction conditions, DKR of 1-phenylethanol (2) was performed delivering $159 \mathrm{~g}(97 \%$ yield) of enantiomerically pure $(R)-1$-phenylethanol acetate (3) in a short reaction time $(20 \mathrm{~h})$ using $0.05 \mathrm{~mol} \%$ of Ru-catalyst 1, and small amounts of enzyme. The employed heterogeneous biocatalyst, Candida antarctica lipase B, catalyzes the transesterification with excellent selectivity in the presence of the homogeneous ruthenium racemization catalyst $\mathbf{1}$. Isopropenyl acetate seems to be an appropriate acyl donor, which makes the purification of the product acetate very easy via simple distillation.

\section{Experimental}

See Supporting Information File 1 for experimental data.

\section{Supporting Information}

\section{Supporting Information File 1}

Large-scale ruthenium- and enzyme-catalyzed dynamic kinetic resolution of ( $\mathrm{rac}$ )-1-phenylethanol: Supporting Information. Experimental procedure of DKR of 2 on 1 mol scale and GLC chromatogram of this experiment. [http://www.beilstein-journals.org/bjoc/content/ supplementary/1860-5397-3-50-S1.doc]

\section{Acknowledgments}

Financial support from the Swedish Research Council and the Swedish Foundation for Strategic Research is gratefully acknowledged.

\section{References}

1. Theil, F. Chem. Rev. 1995, 95, 2203-2227. doi:10.1021/cr00038a017

2. Cossy, J.; BouzBouz, S.; Pradaux, F.; Willis, C.; Bellosta, V. Synlett 2002, 1595-1606. doi:10.1055/s-2002-34233

3. Chen, S.-L.; Hu, Q.-Y.; Loh, T.-P. Org. Lett. 2004, 6, 3365-3367. doi:10.1021/ol048608q

4. Kamal, A.; Khanna, G. B. R.; Ramu, R. Tetrahedron: Asymmetry 2002, 13, 2039-2051. doi:10.1016/S0957-4166(02)00537-2

5. Noyori, R. Asymmetric Catalysis in Organic Synthesis; Wiley: New York, 1994

6. Jacobsen, E. N.; Pfaltz, A.; Yamamoto, H. Comprehensive Asymmetric Catalysis; Springer: Berlin, 1999; Vol. 6 and 29.

7. Palmer, M. J.; Wills, M. Tetrahedron: Asymmetry 1999, 10, 2045-2061. doi:10.1016/S0957-4166(99)00216-5

8. Wills, M.; Palmer, M.; Smith, A.; Kenny, J.; Walsgrove, T. Molecules 2000, 5, 4-18.

9. Ojima, I., Ed. Catalytic Asymmetric Synthesis; Wiley: New York, 2000; Vol. 1 and 8.

10. Bäckvall, J.-E. J. Organomet. Chem. 2002, 652, 105-111. doi:10.1016/S0022-328X(02)01316-5

11. Nishimura, S. Handbook of Heterogeneous Catalytic Hydrogenation for Organic Synthesis; Wiley: New York, 2001.

12. Gladiali, S.; Alberico, E. In Transition Metals for Organic Synthesis, 2nd ed.; Beller, M.; Bolm, C., Eds.; Wiley-VCH: Weinheim, 2004; Vol. 2, pp 145-166.

13. Clapham, S. E.; Hadzovic, A.; Morris, R. H. Coord. Chem. Rev. 2004, 248, 2201-2237. doi:10.1016/j.ccr.2004.04.007

14. Gladiali, S.; Alberico, E. Chem. Soc. Rev. 2006, 35, 226-236. doi:10.1039/b513396c

15. Corey, E. J.; Helal, C. J. Angew. Chem., Int. Ed. 1998, 37, 1986-2012. doi:10.1002/(SICI)1521-3773(19980817)37:15<1986::AID-ANIE1986>3 .0.CO; $2-\mathrm{Z}$

16. Riant, O.; Mostefaï, N.; Courmarcel, J. Synthesis 2004, 2943-2958. doi:10.1055/s-2004-834932 And reference therein.

17. Soai, K.; Niwa, S. Chem. Rev. 1992, 92, 833-856. doi:10.1021/cr00013a004

18. Zhu, H. J.; Jiang, J. X.; Ren, J.; Yan, Y. M.; Pittman, C. U., Jr. Curr. Org. Synth. 2005, 2, 547-587. doi:10.2174/157017905774322677

19. Nicolau, K. C.; Snyder, S. A. Classics in Total Synthesis II; Wiley-VCH: Weinheim, 2003.; pp 31-74

20. Machajewski, T. D.; Wong, C.-H. Angew. Chem., Int. Ed. 2000, 39, 1352-1374. doi:10.1002/(SICI)1521-3773(20000417)39:8<1352::AID-ANIE1352>3. $0 . \mathrm{CO}$;-J

21. Sawamura, M.; Ito, Y.; Carreira, E. M. In Catalytic Asymmetric Synthesis, 2nd ed.; Ojima, I., Ed.; Wiley-VCH: New York, 2000; pp 493-541.

22. Palomo, C.; Oiarbide, M.; García, J. M. Chem. Soc. Rev. 2004, 33, 65-75. doi:10.1039/b202901d

23. Saito, S.; Yamamoto, H. Acc. Chem. Res. 2004, 37, 570-579. doi:10.1021/ar030064p

24. Nakamura, K.; Matsuda, T. Curr. Org. Chem. 2006, 10, 1217-1246. doi:10.2174/138527206777698020

25. Wong, C.-H.; Whitesides, G. M. Enzymes in Organic Chemistry; Pergamon: Oxford, 1994.

26. Bornscheuer, U. T.; Kazlauskas, R. J. Hydrolases in Organic Synthesis, Regio- and Stereoselective biotransformations; Wiley: Weinheim, 1999. 
27. Faber, K. Biotransformations in Organic Chemistry, 5th ed.; Springer: Berlin, 2004.

28. Silverman, R. B. The Organic Chemistry of Enzyme-Catalyzed Reactions; Academic Press: San Diego, 2002.

29. Pàmies, O.; Bäckvall, J.-E. Chem. Rev. 2003, 103, 3247-3261. doi:10.1021/cr020029g

30. Kim, M.-J.; Anh, Y.; Park, J. Curr. Opin. Biotechnol. 2002, 13, 578-587. doi:10.1016/S0958-1669(02)00347-6 And erratum 2003, 14:131

31. Martín-Matute, B.; Bäckvall, J.-E. Curr. Opin. Chem. Biol. 2007, 11, 226-232. doi:10.1016/j.cbpa.2007.01.724

32. Martín-Matute, B.; Edin, M.; Bogár, K.; Bäckvall, J.-E. Angew. Chem., Int. Ed. 2004, 43, 6535-6539. doi:10.1002/anie.200461416

33. Choi, J. H.; Choi, Y. K.; Kim, Y. H.; Park, E. S.; Kim, E. J.; Kim, M.-J.; Park, J. J. Org. Chem. 2004, 69, 1972-1977. doi:10.1021/jo0355799

34. Martín-Matute, B.; Edin, M.; Bogár, K.; Kaynak, F. B.; Bäckvall, J.-E. J. Am. Chem. Soc. 2005, 127, 8817-8825. doi:10.1021/ja051576x

35. Kim, N.; Ko, S.-B.; Kwon, M. S.; Kim, M.-J.; Park, J. Org. Lett. 2005, 7, 4523-4526. doi:10.1021/ol051889x

36. Borén, L.; Martín-Matute, B.; Xu, Y.; Cordova, A.; Bäckvall, J.-E. Chem.-Eur. J. 2006, 12, 225-232. doi:10.1002/chem.200500758

37. Ko, S.-B.; Baburaj, B.; Kim, M.-J.; Park, J. J. Org. Chem. 2007, 72, 6860-6864. doi:10.1021/j0071065o

38. Klibanov, A. M. Acc. Chem. Res. 1990, 23, 114-120. doi:10.1021/ar00172a004

39. Klibanov, A. M. Nature 2001, 409, 241-246. doi:10.1038/35051719

40. Hansen, K. B.; Chilenski, J. R.; Desmond, R.; Devine, P. N.; Grabovski, E. J. J.; Heid, R.; Kubryk, M.; Mathre, D. J.; Varsolona, R. Tetrahedron: Asymmetry 2003, 14, 3581-3587. doi:10.1016/j.tetasy.2003.08.043

41. Badone, D.; Guzzi, U. Bioorg. Med. Chem. Lett. 1994, 4, 1921-1924. doi:10.1016/S0960-894X(01)80535-7

\section{License and Terms}

This is an Open Access article under the terms of the Creative Commons Attribution License (http://creativecommons.org/licenses/by/2.0), which permits unrestricted use, distribution, and reproduction in any medium, provided the original work is properly cited.

The license is subject to the Beilstein Journal of Organic Chemistry terms and conditions:

(http://www.beilstein-journals.org/bjoc)

The definitive version of this article is the electronic one which can be found at: $\underline{\text { doi:10.1186/1860-5397-3-50 }}$ 